\title{
Wilms Tumor-Aniridia-Genitourinary Anomalies-Mental Retardation Syndrome
}

National Cancer Institute

\section{Source}

National Cancer Institute. Wilms Tumor-Aniridia-Genitourinary Anomalies-Mental

Retardation Syndrome. NCI Thesaurus. Code C3718.

A very rare congenital condition involving the complex of Wilms tumor, aniridia, genitourinary abnormalities, and mental retardation. Wilms Tumor-Aniridia-Genitourinary Anomalies-Mental Retardation (WAGR) syndrome involves deletions of several adjacent genes in chromosome region 11p13. Two or more of the four conditions must be present for an individual to be diagnosed with WAGR Syndrome. The clinical picture varies, depending upon the combination of abnormalities. 